Investigations of the toxicity of various substances and the effects of temperature on fish continue. In these studies, and also in work on biological treatments of sewage, cyanides and phenols, it is interesting to see the growing significance of acclimatization of the organism or the community. Most of the toxicity studies have been based on mortalities during relatively short periods of exposure, and it would now seem necessary to study the effects of much longer exposures on the growth, longevity and reproduction of fish.

The survey of the Thames estuary, which has been an important part of earlier reports, is now nearing completion. Some examples of the difficulties that arise in predicting the behaviour of this intricate system are to be found in this report. Recent improvements in the treatment of some of the sewage discharged to the estuary have apparently not produced the expected improvement in estuarine conditions for much of the year. It seems probable that dredging may have to be added to the numerous factors which must be considered, as it appears that a concurrent reduction in the removal of organic matter in this way could have masked the effects of the improvements.

It may be helpful to direct attention to two errors which might lead the reader to erroneous conclusions. In Fig. 4, p. 13, the continuous lines refer to a depth of $3 \mathrm{ft}$. and the broken lines to $15 \mathrm{ft}$., not vice ver'sa as in the key given. In a section describing the work of the reviewer while at the Laboratory (p. 85), the last paragraph should start, "The gross rates of oxygen production are nearly twice (not ten times) published values for various aquatic plants in optimum light but in stagnant vessels. Static values for the plants used, obtained by extrapolating the flow curves, are much lower than the experimental stagnant results".

\title{
UNIVERSITY OF OXFORD SECOND TANGANYIKA EXPEDITION
}

$\mathrm{W}$ ITH the encouragement of the Government of Tanganyika, a second party from the University of Oxford visited the Mahali Mountains on the eastern shore of Lake Tanganyika during July to October to continue the work started by last year's expedition (see Nature, 183, 726 ; March 14, 1959).

The Mahalis form a small, well-defined, yot little known region, not typical of most of Tanganyika, where flora and fauna of East and West Africa meet. Whereas last year's expedition concentrated on the southern half of the peninsula, this year the base camp was farther north, at Kasoge, a short distance from Mount Kungwe (c. $8,250 \mathrm{ft}$.), the highest peak in the range.

A collection of plants at all altitudes above lakelevel was made by R. M. Harley and J. G. B. Newbould, of the Botany School, Oxford. The specimens have been sent to the Royal Botanic Gardens at Kow for identification and will be used in the preparation of the Flora of Tropical East Africa. The collection includes a number of live orchids which are now in the orchid houses at Kew.

The two zoologists made a general collection of birds, snakes and small mammals and also specialized in Arachnida and freshwater biology. J. A. Cooke, of the Zoology Department, Oxford, made an exhaustive study of the spiders in the area and collected nearly 4,000 specimens. D. H. Eccles, of the Bureau of Animal Population, Oxford, collected several hundred fish from the streams draining into Lake Tanganyika, using both poison and electric shock methods. For two weeks the party was joined by G.H. Yeoman, of the Tanganyika Veterinary Department, who was investigating parasites on small mammals.

W. J. Wadsworth and R. C. Herrera, of the Department of Geology, Oxford, made a geological investigation of the layered igneous intrusion at Kapalagulu, about 20 miles north-east of Mount Kungwe. T. E. Stevens, of the same Department, completed a survey of the Mount Kungwe region itself. Collections of rock specimens from these two areas will be examined in the Department of Geology, Oxford, and at the Geological Survey, Dodoma, Tanganyika.

R. Davis, of the Institute of Experimental Psychology, Oxford, conducted experiments on reaction times and visual perception among local inhabitants and tested 350 children in missions and native authority schools as part of a comparative study of African and European children. A household survey of villages in the northern half of the peninsula was also undertaken.

The members of the expedition participated in the social activities of the region and various features of local life were recorded, both photographically and on magnetic tape.

R. Davis

\section{GEOMAGNETIC ACTIVITY AT HALLEY BAY ON DISTURBED DAYS}

\author{
By J. MACDOWALL \\ Meteorologica! Office, London
}

\begin{abstract}
$\mathrm{T}$ HIS examination of the diurnal variation of geomagnetic activity at Halley Bay, lat. $75^{\circ} 31^{\prime}$ S., long. $26^{\circ} 37^{\prime} \mathrm{W}$., was based on $Q$-indices which occurred during the five most disturbed days in each month. A year was formed from the twenty months observations and then divided into four seasons.

Greatest activity oceurred for the seven hours after local midnight in each season, but a significant
\end{abstract}

seasonal change occurred in the form of the daily variation.

Fig. 1 shows that the mean activity of the year was of a similar form to the diurnal variation at the equinox. However, Fig. 2 illustrates the marked seasonal change in the form of the diurnal curve. Near local midnight, activity started earliest in winter and latest in summer, but activity after mid- 